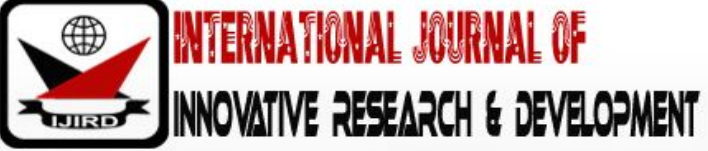

ISSN 2278 - 0211 (Online)

\section{Environmental Challenges and Conservation of Natural Resources: The Need for Effective Environmental Mechanisms}

Ahmadu Muhammad Nasir
Principal Lecturer, Department of General Studies,
Taraba State Polytechnic, Suntai, Nigeria
Doreen Thomas Fom
Principal Meteorologist, Department of Planning \& Design,
Lower Venue River Basin Development Authority, Makurdi, Nigeria

\begin{abstract}
:
The national environmental program is geared towards reducing the negative impacts of human operations on the environment so as to enhance an eco-friendly atmosphere. The objective is to minimize and, where possible, eliminate all the negative impacts and footprints, in a collective drive to protect the environment. Therefore, the National Policy on Environment identified the key sectors of the economy that require the integration of environmental concerns and sustainability with development. The needs to conserve natural resources and manage waste generated by the increasing population were discussed. Corruption was pointed out as a key challenging factor to the implementation of environmental regulatory policies. Inclusion of green chemistry policy, enactment of its enabling laws as well as effective implementation of environmental protection policies were recommended to enhance national sustainable development.
\end{abstract}

Keywords: Environmental challenges, environmental policy, conservation, natural resources

\section{Introduction}

In the 1960s, environmental issues surfaced with great awareness. However, this was limited to the industrialized countries (Pearce and Turner, 1990). In the United States, for example, the concern over the environmental degradation reached a critical point in the 1970s; thus, Erskine (1972) was able to characterized 'the unprecedented and urgency with which ecological issues have burst into American consciousness' as 'a miracle of public opinion'. In the developing countries, the recognition of the need for policy to protect the environment is a much recent undertaking. Preoccupied with the high level of ignorance and its attendant poverty; environmental protection ranked low on the list of priorities of developing countries. But this altitude is changing, although the specific details may vary, as many countries are now united in a crusade to protect the environment (Felix and Robert, 2010). Until recently, there was little awareness about the fact that damage to one part of our environment, whether it is living or non-living, can affect other parts of our environment in a subtle and unknown ways. The dramatic change in perception of the international development community stemmed from this awareness that environmental problems are trans-national issues that must be addressed jointly by the industrialized and developing countries. Consequently, conferences have become a powerful rallying medium for articulating the need for substantive environmental policies at the national, international and regional levels. This paper therefore seeks to look at some of our environmental challenges and the role of environmental policy in conserving our natural resources towards sustainable national development.

\section{Development Challenges on Environment}

The importance of technological development on the economic growth and development of the nation was documented by Shaibu (2010). However, it has long been recognized that development can have major effects on the environment. The concept of sustainable development goes well beyond this acknowledgement by also considering the effects of environment on development (Felix and Robert, 2011). Due to the quest for industrialization and technological advancement, Nigeria is faced with the environmental task of coping with the environmental problems that are local to our geographical location as well as global environmental problems, which have their origin chiefly in the wealthy industrialized nation. Similarly, some of the domestic environmental problems of Nigeria have major international implications. Therefore, the current agitation for an eco-friendly environment '.... was due to the sahelian droughts, floods, forest fires, technological accident involving oil spills, industrial chemical effluent and the increased visibility of toxic waste dumping and contamination of rivers, lakes, soil and air (Egunjobi 1993, James 1993, Adeola 1996). There is need for better understanding of some of the environmental problems and the appreciation of the role of environmental policy in conserving the environment and its resources towards a sustainable development. This is because industrialization is 
accompanied with the generation of wastes, some of which are toxic and very hazardous to human existence. The ecosystem is also affected adversely by technological advancement leading to cases like desertification, flooding, erosion, indiscriminate dumping of waste, etc., with its resultant increase in the poverty profile of the nation. Similarly, increasing population as predicted by the National Population Commission (NPC) to hit 178,5721 people and with an annual population growth rate of 3.2 percent () (this day newspaper ,2011) exerts its adverse effects of the environment as each individual generates waste which may not be effectivewly controlled and treated as well as contributing significvantly to the degradation of existing natural resources.a population of more than 167 million people with annual growth rate of 3.2 percent

\section{Natural Resources}

These are resources which occur naturally and are useful to man. They can be classified as renewable or nonrenewable resources derived from the environment. Renewable resources are those that can be replenished or reproduced easily in nature at a rate close to their rate of use. Some of them like wind, sunlight, etc. are continuously available and their quantity is not affected by human consumption. Others can be depleted by human use, but can be replenished thus maintaining a flow. On the other hand, non-renewable resources are those formed over long geological periods, like minerals and fossil fuels. Since their rate of formation is extremely slow, they cannot be replenished at the same rate at which they are depleted (Ngozi-Olehi, 2009). Of the theses, the metallic minerals can be re-used be recycling them, but coal and petroleum cannot be recycled.

On the basis of availability, natural resources can be classified as 'exhaustible natural resources' and 'inexhaustible natural resources.' Inexhaustible natural resources are those resources that are present in unlimited quantity in nature and are not likely to be exhausted easily by human activity (e.g. sunlight, air, etc.). Exhaustible natural resources are those resources that are present in limited amounts and hence, can be exhausted by human activity in the long run (e.g. coal, petroleum, natural gas, etc.).

\section{Conservation of Natural Resources}

This is the wise use of the earth's resources by humanity. The term 'Conservation' came into use in 19th century and referred to the management, mainly for economic reasons, of such valuable natural resources as timber, fish, game, topsoil, pastureland and watershed areas (Wikipedia). In recent years, the science of ecology has clarified the workings of the biosphere as regards the complex inter-relationships among humans, other animals, plants and the physical environment. At the same time, increasing population and industrial growth with its resultant pollution have demonstrated how delicately balanced the ecological relationships can be disrupted.

Conservation of natural resources is now embraced in the broader conception of conserving the earth itself by protecting its capacity for self-renewal. Particularly complex are the problems of non-renewable resources such as oil, coal and other minerals in great demand. But current thinking also favours the protection of entire ecological regions by the creation of 'Biosphere reserves.' Examples of such conservation areas include the 'Great Barrier Reef', of Australia, 'Adirondack State Park' in the United State, Yankari Game Reserve and Gumti National Park' in Nigeria.

The conservation of natural resources is of great importance because the continuous consumption of non-renewable resources coupled with the fact that man is using the renewable resources at a rate that exceed the restorative powers of natural possess great concern. In the midst of these challenges, man is increasingly acknowledged to be the principal contributor to the deterioration of his environment and the decline in the quality of life.

\section{Environmental Challenges}

Environmental challenges as it is today is as the result of the deterioration of the Environment through depletion of resources, destruction of ecosystems and the extinction of some living components of the environment. These problems may fall into two categories:

- The problems of ignorance and its associated poverty, and;

- The problems that arise out of the very process of development.

These problems are reflected in the poor social and economic conditions that prevail in both the rural and urban areas. As the wind of globalization blow across the world and that of development in Countries like Nigeria, the problem of resource depletion and pollution (among others) possess great challenges. Fossil-fuel sources of energy such as oil and coal are exhaustible and also pollute the air, water and contribute to global warming. Even the hydro-electric power plants like Kainji dam and other dam projects have displaced thousands of people and destroyed ecosystems in recent times. The over dependence of the Nigerian economy on oil revenues as well as the inability of government to control the technological process involved in oil exploration and production, have freed the oil industry from any major sense of social responsibility towards their communities. Forestry and other low priority sectors are often hitby cutbacks in staff and expenditure imposed by economic austerity programs, and these programs combined with economic stagnation intensity pressure on the poor. There is also a high demand in industrialized nations for Nigerian timber and other commodities grown at the expense of forests. These lead to deforestation, desert encroachment, extinction of some plant and animal species, erosion, leaching and low agricultural productivity. the frequency of environmental hazards in the operations of the Nigerian Oil industry reflect human error, corporate recklessness and sheer insensitivity of the oil companies to the needs for environmental protection (Felix and Robert, 2010). This is because the sources of environmental hazards in Nigerian oil industry include flow-line leaks, over pressure failure, sabotage of well heads and flow line, hose failures on loading systems and failure along pump discharge manifolds (Ikein, 1990), in 1970, there was a blow-out at Borne Oil Field. 
Baker (1985) reported that the blow-out released about 400,000 barrels of crude oil into the environment; affecting farmlands, water bodies, etc. The disillusioned farmers, dispossessed fishermen and frustrated communities do not see the invisible Federal Government who are shareholders in these companies nor their greedy leaders who are interested in themselves alone. What the communities see are the oil rigs and the companies who they think are the visible expression of environmental genocide. However, the activities of the oil companies have disrupted the ecology of the oil producing Niger Delta Basin' (Baker, 1985); and the 'tales of paralyzed social and economic lives due to oil spillage are as old as history of oil exploration in Nigeria' (Ayeni, 1992). Olusi (1981) has documented the negative impact of oil-related pollution on health. Oil spills deprive the farmland of vital nutrients (Felix and Robert, 2010) and it has become a 'nostalgic in many parts of the oil-producing area to think of fresh fish soup' (Akinmalodun, 1976). These challenges are not limited to the oil-producing areas alone as 'about half of Nigerian population is at risk due to environmental degradation' (Ayeni, 1992). National food shortage together with its associated problems would appear to be inevitable due to the industrial revolution coupled with the quest for white collar jobs and decline in agricultural productivity and the fact that 'more mouths' are coming into the society. Among these problems is the fact that Nigeria's economy suffers enormously as losses due to environmental degradation have been put above 1.5 billion US dollars (Ayeni, 1992).

\section{The Need for Effective Environmental Policy}

Environmental policy generally has to do with a set of principles by which a country regulates its utilization and conservation of the environment for the purpose of achieving its national developmental objectives. A country's environmental policy is concerned with the methodology of planning, classifying, prioritizing and organizing resources as well as establishing institutional mechanisms designed to achieve national goals. Policy in itself has several connotations but all carry the implication of choice (Norman, 1996).

As the result of the challenges of environmental degradation, the Nigerian military government sounded the alarm coupled with public demonstrations for ecological sanity which pressurized the federal and state governments to produce policies or decree with respect to environmental issues. These policies that evolved include the Endangered Species Degree of 1985, National Conservation Strategy for Nigeria 1986, the Natural Resources Conservation Council Decree 1989 and the Federal Environmental Protection (FEPA) Decree of 1989. A remarkable event that led to the creation of FEPA in 1989 was the discovering of an Italian ship in May, 1988, loaded with chemical waste of mainly polychlorobiphyls (PCBS) which resulted in hostile media reaction, as Nigeria lacked both the institutional and legal framework to tackle the issue. The environmental alarm is still being sounded but is increasingly drown-out by warnings of other crises like political instability, low economic productivity, education and high crime rate. Many environmental policy interventions in Nigeria are regulatory, and seek to control the activities of both the public and private sectors in areas such as pollution, disposal of hazardous and toxic wastes, and health standards. Green Chemistry policy (which is a new concept in coping with environmental challenges applies highly effective innovative scientific solution to real environmental problems, reducing or preventing pollution at its source) should be given indebt attention (Ngozi-Olehi, 2010). Such policies, in order to be effective, require adequate funding and trained staff, who are usually in very short supply and unlikely to remain untouched by the graft and corruption which frequently surround them; and often form a part of their activities.

Francis (1996), Valentine (1993) and choker (1993) assert that the most reliable indicators of the policies of governments towards environmental problems are how they are organized to deal with environmental issues and the amount of money allocated to address the problems. However, one of the noticeable changes today is that corporate elites have begun to recognize that environmental problems do exist, and seem to develop and ideology that either absolves them of responsibility or portrays them as best hope for solving them problems or both. This change is a function of politics rather than a matter of newborn corporate morality (Felix and Robert, 2010). But it will be a shift in the right direction if it is genuinely sustained. NESREA (National Environmental Standards and Regulations Enforcement Agency) was established as an environmental regulatory body but unfortunately, most small- and large-scale industries in Nigeria that contribute greatly to these environmental damages are not 'aware' of their existence and therefore go about their businesses without recourse to stand of NESREA on their activities. This is not good for national development and environmental safety. Corruption which has eaten deep into the fabrics of his nation make environmental regulatory agencies to compromise their standards thereby making a mess of the policies they formulated and the objectives of their establishments defeated. We can only safeguard our environment and have healthy living if these regulatory bodies improve their policies with the dynamic world and keep to them.

\section{Conclusion}

There is an increasing awareness that environmental degradation is a plaque to be conquered and modified for a better human welfare. This emerging consensus tends to support the idea that human being are stewards of their geophysical environments. The underlying logic is that by protecting and maintaining its integrity, the environment will serve the needs of man far into the future. This is an important argument in environmental ethics that should be the pivot in designing policies which will be used as instruments in conserving the environment and its resources. The national policies have not been effective in addressing the environmental problems because of the necessary managerial framework for their implementation, inadequate funding and qualified personnel as well as corruption. It is our believe, that environmental issues be given top priority on the demand of the citizens of Nigeria from their elected officials.

\section{Recommendations}

The following recommendations are thus made: 
- The issue of institutional arrangement for the management of the environmental policy should be properly addressed in a more systematic fashion for proper implementation.

- Every member of the community needs to be informed so as to be responsible towards the conservative use of available resources in view of the need for self-sufficiency and independence from outside support.

- The school curriculum should be upgraded to cover all the necessary environmental awareness especially at the early stage so that those that cannot continue in the environmental sciences will still have inbuilt knowledge of the environment whenever in a position to formulate or implement environmental policies.

- Population stabilization should be closely considered in future environmental policies. This is because increase in population affects the degradation of the environment which can even result in difficulty in controlling the rate of poverty in the society.

- The knowledge of Green Chemistry should be made available to everyone in the society as well as green chemistry laws enacted. This will encourage proper recycling of waste product, production and utilization of fertilizers, biomass, appropriate application of pesticides, etc.

Finally, the remedial approaches to environmental problems are closely interwoven with policies for sustainable development. These policies should embrace wider dimensions than the growth of gross national product and must include some of the major environmental problems that arise in the context of urban and rural poverty.

\section{References}

i. Adeola, F. (1996): 'Environmental Contamination, Public Hygiene and Human Health Concerns in the Third World: The case of Nigeria environmentalism'. Journal of environmental Behaviour, volume 28, No. 5, Pp. 614646.

ii. Aina, E. O. A. and Adedipe, N. O. (1991). 'The making of Nigerian Environmental Policy'. Ibadan University Press.

iii. Alachi, J. A. (2008). 'Theatre for Development in the Benue Valley'. Makurdi - Nigeria, Bookmakers Publishers, Pp. 1 - 14.

iv. Ayeni, O. (1992). 'Nigeria: Rectifying the Damage'. West African Publishers (13 - 19th May), Pp. 75.

v. Baker, M. (1985). 'World Environmental Handbook'. New York - The World Environmental Centre.

vi. Choker, B. (1993). Government Policy and Environmental Protection in the Developing World: the example of Nigeria'. Journal of environmental Management, volume 17, No. 1, Pp. 15 - 30.

vii. Ejunjobi, L. (1993). 'Tssues in Environmental Management for Sustainable Development in Nigeria'. The Environmentalist', volume 13, No. 1. Pp. 33 - 40.

viii. Erskine, H. (1972). The Pools: Pollution and its costs. Public Opinion Quarterly, Pp. 36, 120 -135.

ix. Ikein, A. A. (1990). The Impact of Oil on Developing Country: The case of Nigeria. New -York Praeger Publishers.

x. Ngozi-Olehi, L. C.; Okenyi, B. and Njoku, B. A. 'Policy Framework for Green Chemistry: National Development Challenges in focus', A paper presented at the 33 ${ }^{\text {rd }}$ Annual International Conference, Workshop and Exhibition of the Chemical Society of Nigeria - $20-24^{\text {th }}$ September, 2010.

xi. Ngozi-Olehi, L. C, (2009). 'Biogas Production: A study of Optional Condition affecting Gas Yield'. A Ph.D Thesis presented to the Post Graduate School, Federal University of Technology, Owerri.

xii. Norman, O. (1996). 'Economic Development and Environmental Policy'. New - York, Kegan Paul International.

xiii. Olusi, O. S. (1981). Nigeria Oil Industry and the Environment', Proceedings of the 1981 International Seminar, Lagos - Nigeria.

xiv. Pearce, D. W. and Turner, R. K. (1990). 'Economics of Natural Resources and the Environment'. Baltimore, John Hopkins University Press.

xv. Shaibu, O. G. 2010. Information and Communication Technology (ICT) as a Tool for Sustainable Educational Development in Nigeria'. School of Agriculture and Vocational Studies, Alvan Ikoku Federal College of Education, Owerri.

xvi. Wikipedia, the Free on - line encyclopedia.

xvii. http:/ / www midterm.us/ blog-term-paper-examples/ term-paper-on-nigeria.html. 17/ 12/ 2019.

xviii. http:/ / www.infoplease.com/ ce6/ sci/ AO8/ 3290.html. Natural Resources', Retrieved: 1712/ 2019. 